\title{
E-Government Effect on Participatory Democracy in the Maghreb: Indirect Effect and Government-Led Participation
}

\author{
Sami Esselimani ${ }^{D},{ }^{1}$ Mustafa Sagsan $(\mathbb{D}){ }^{2}$ and Sevki Kiralp ${ }^{3}{ }^{3}$ \\ ${ }^{1}$ Department of Innovation and Knowledge Management, Faculty of Economics and Administrative Sciences, \\ Near East University, Nicosia 99138, North Cyprus, Mersin 10, Turkey \\ ${ }^{2}$ Department of Business Administration, Faculty of Economics and Administrative Sciences, Cyprus International University, \\ Nicosia 99258, North Cyprus, Mersin 10, Turkey \\ ${ }^{3}$ Department of Political Science, Faculty of Economics and Administrative Sciences, Near East University, Nicosia 99138, \\ North Cyprus, Mersin 10, Turkey
}

Correspondence should be addressed to Sami Esselimani; esselimanisami@gmail.com

Received 20 December 2020; Revised 23 February 2021; Accepted 19 March 2021; Published 1 April 2021

Academic Editor: Binxiang Dai

Copyright (c) 2021 Sami Esselimani et al. This is an open access article distributed under the Creative Commons Attribution License, which permits unrestricted use, distribution, and reproduction in any medium, provided the original work is properly cited.

\begin{abstract}
The evolution of the concept of democracy throughout decades of theory and practice has led to the firm understanding that democracy is progressive in terms of thought and practice. An important feature of democracy is the ability of individuals to discuss and participate in matters of public interest. E-government offers an opportunity for governments and citizens to engage in more deliberate practices of democracy. This paper focuses on the Maghreb region (Algeria, Morocco, and Tunisia) and discusses the direct effect of e-government on participatory democracy and also the indirect effect, which is referred to as the "indirect government-led relationship" between e-government and participatory democracy. A quantitative approach was adopted, and a questionnaire was distributed using a nonprobability, judgement sampling method, which focuses on a population with specific knowledge and expertise. A total of 702 answers were collected. The results show that e-government positively affects participatory democracy directly and also indirectly through increasing corruption control, transparency, and accountability.
\end{abstract}

\section{Introduction}

Citizens' involvement in politics is a necessity for any democracy. However, this involvement needs to be motivated by awareness and knowledge. The conflict between the elitist view of democracy and the deliberative view is based on the ability of the general public to understand the complicated political issues [1]. Therefore, representative, pluralist, and deliberative models of democracy depend on the extent to which people can develop political awareness and their ability to access information. Habermas argues that the deliberative approach is the best when applicable [1].

The advance of information and communication technologies now allows citizens to access information and be better informed through e-government services and other different communication channels at a very low cost. On the one hand, this advance indeed empowers citizens and civil society organizations to speak out and practise their right of controlling and questioning both central and local governments' actions and polices; on the other hand, it serves to put pressure on governments and their representatives in parliaments to fulfil their duties.

Although it has not been sufficiently explored, and sometimes is referred to as the participatory e-government [2], the relationship between e-government and participatory democracy seems to be logical and possible based on the existing literature of both topics. Therefore, this paper aims to study the relationship between e-government and participatory democracy in the Maghreb countries, which are developing countries. The Maghreb region differs in terms of income, economics, and political models but shares complex characteristics such as demographics (a mix of Arabs and 
Berbers), history (ex-French colonies), and culture (French/ Arabic-speaking countries). Thus, the Maghreb countries are homogenously consistent, which makes them a suitable region to focus on.

The environment created by ICTs in general, and by e-government in particular, seems to be prodemocratic.

Previous studies have focused on e-democracy as a final phase of the full adoption and integration of ICTs in established democracies [3,4], whereas this study focuses on the relationship between e-government and participatory democracy in developing countries and the potential for e-government to play a facilitating role in the democratic change process in nondemocratic countries.

1.1. E-Government Overview. International organizations such as the World Bank and the United Nations define e-government as the adoption and integration of information technologies (Internet, mobile computing, and widearea networks) within government agencies, transforming the relationship with their different customers (citizens, businesses, other government agencies, etc.) [5]. The use of information technologies aims to digitalise workflows and processes in order to enhance data and information management [6].

The application of these technologies in public administration can lead to different positive outputs, such as enhancing the delivery of government services, better interaction with different organizations (e.g., businesses and associations), citizens' empowerment [5], and engagement by facilitating access to information [6]. According to the World Bank, the effective adoption and use of information technologies to deliver government services can decrease corruption, provide more transparency, reduce costs, and increase revenue [5].

DeBenedictis et al. [7] argued that the use of information technology can enhance accountability and the quality of government activities, which include service delivery, providing easy access to information and encouraging citizens and organizations toward direct participation. In this sense, e-government is expected to bring the government closer to its citizens [8].

E-government, according to Grant and Chau ([9], p. 80), has three major activities which are (1) integration of highquality public services, (2) providing effective management of the relationship with citizens, and (3) supporting citizens and civil society's goals of development on economic and social levels locally, nationally, and internationally.

Accordingly, e-government can be characterized as a reengineering of information provision to citizens by the public administration to achieve added value. Therefore, three major e-government relationships can be distinguished between the three actors, as shown in Figure 1.

E-government here is considered as a body that is composed of the interaction of three parts, which are e-democracy, e-administration, and e-service. E-democracy represents citizens' relationship with the state; e-service represents the relationship between citizens and public administration, whereas e-administration is the digitalisation of the processes and procedures within the governmental agencies to provide support for decision makers $[10,11]$. Although e-democracy is not included in e-government definitions [12], other researchers still agree with the three-dimensional model of e-government $[13,14]$.

Efficiency is the key word for successful e-services that aim to rationalize public administration expenses and offer more accessible and readily available services. We can observe similarities between e-services and e-commerce that are inherited from the similarities of the public and the private sectors. Nevertheless, the main technical difference is that demand in private sector is market-oriented, whereas public services, electronic or nonelectronic, lack the flexible market information structures. Moreover, the supply of public services is constrained by the availability of resources, which are basically taxes and fees, and also by prioritization and legal application. Therefore, digitalisation of public services is subject to its resources [10].

Vintar et al. [15] argue that e-administration can be either a radical reengineering of administration or just another stratum to be added to a traditional administration. The latter is the case in many developing countries such as the Maghreb countries. In the light of this, e-administration introduces new relationships, which is referred to as vertical and horizontal integration [16]. According to Cordelia [17] the principles of New Public Management NPM, such as decentralisation and flattened bureaucracy, are better served with e-administration. This basically happens while access to information by other public bodies is made easier through digitalisation.

1.2. Participatory Democracy in Debate. Many theorists agree that democracy in its basic form should not be the sole form of governance where leaders or parties gain legitimacy to represent citizens by merely participating in elections. The elite view of democracy supported by Mosca and Pareto has attracted interest for a long time. They claim that democracy is a regime that legally gives the elites the authority to govern. In other words, democracy according to them is a regime where the elites rule and the masses follow [18]. However, supporters of participatory democracy believe that the participatory concept is a progressive concept of democracy.

The inclusion of citizens in decisions on matters that directly concern them has not only become a demand for social movements, but also a priority for the different governments. In the participatory field, Latin America is one of the most fertile regions in experimentation and innovation. Brazil's "participatory budget," set up in Porto Alegre in 1989, is the most striking example of a participatory dynamic. As an icon of participatory democracy, this device has experienced an intense movement on a global scale.

The participative phenomenon was accompanied by the emergence of intense growth in the social sciences, contributing to the crystallization of rich literature on the subject. Certain works about democratic theory [19] consider participation as one of the elements that should be taken into account when evaluating the quality of a 


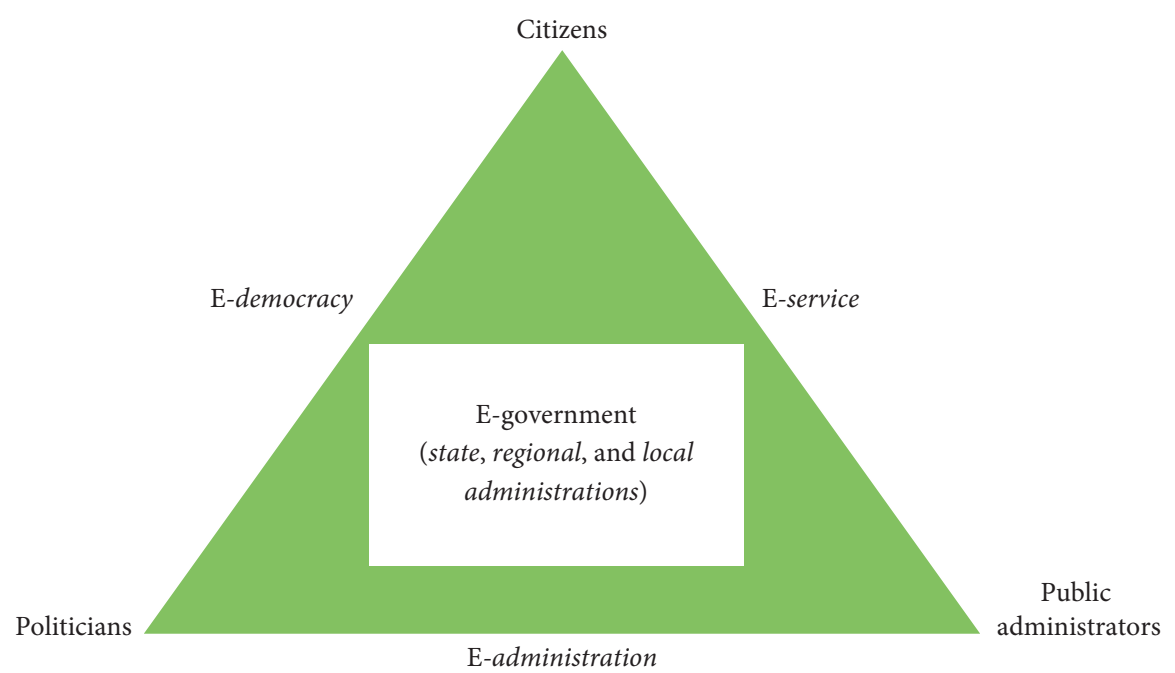

FIGURE 1: E-government relationships model (source: [10]).

democratic regime. Another approach, represented by Fung and Wright [20] in the United States and Lubambo et al. [21] in Brazil, uses case studies to observe the institutional conditions favourable for the deepening of democracy. The participatory dimension of democracy is also addressed by the prism of the type of broader political projects carried out by those who implement it [22].

It was in the 1960s that the debates over participatory democracy intensified. During that period, democracy witnessed new endeavours that completely rethought the concept, which was led by authors such as Barber and Carole Pateman [23]. Until that time, democracy considered citizens' participation to be limited to voting, and after that, the public decision was entrusted to politicians. For social participation thinkers, citizens should be involved in decision-making processes.

Inspired by Rousseau, Carole Pateman discussed a participation-based democratic theory in his book Participation and Democratic Theory, published in 1970. Pateman focused on the educational role of participation. As for Rousseau, citizens learn to seriously consider public interest issues that go beyond their personal interests, while Pateman considers that individuals learn through participation that private and public concerns are strongly related. Pateman suggests that democracy is established and learned when citizens participate. Participation starts at local levels where people learn to govern themselves in social spheres as a preparation before their effective participation in politics $[24,25]$. This argument emerged to oppose the claim of Schumpeter, who considered citizens to be intellectually deficient in terms of being able to act or decide in political matters.

The participatory dimension of democracy is also at the heart of the work of Benjamin [26]. While the main concern of Pateman is to reintegrate participation in democratic theory, Benjamin Barber questions whether the problems of excessive liberalism could lead to democracy. The possible degenerations of liberalism can become a pathology of the political system, characterized by problems of political passivity or totalitarian temptations. Convinced that liberal democracy does not correspond to the best political device that human beings can aspire to, the author proposes the alternative of strong democracy.

Strong democracy is a contemporary and distinct form of participatory democracy, centred on "the idea of a community self-managed by citizens, united by civil education and capable of pursuing common objectives and mutual actions, for the sake of their civic behaviour and participatory institutions, rather than altruism and beneficent nature" [26]. This alternative, which focuses on transformation and change, is mobilized to resolve the dilemmas of modern conflict-ridden politics. Furthermore, for this author, in strong democracy, participation in policies is essential and conflicts are resolved through the participatory process and self-management, in which the community is able to ensure that private interests become public goods ([26], p. 132).

The debate on democracy has gone further and turned to the internal procedures of the participatory process, that is to say, the deliberative dimension. This is a facet of democratic theory that has gained new momentum since the mid-1980s. Much of the deliberation debate feeds on the insights developed by Jürgen Habermas. Among his most significant contributions are reflections on the category of "public," often translated as the "public sphere" (from the original German term Öffentlichkeit). The author has resumed the debate between republicanism and liberalism, arguing that the democratic process is what distinguishes them from each other.

In liberalism, the state must plan in consultation with the interests of society, leaving enough space for the development of private interests, while in republicanism, the state must be a constituent element of society as a whole [27]. According to the republican conception, there is solidarity and orientation towards the public interest as the third source of social integration, in addition to administrative power and individual interests ([27], p. 40). Besides, the existence of an autonomous and independent base of civil 
society is essential for the self-determination of citizens to be effective.

Although he believes that republicanism is advantageous because it offers a radical proposal of democracy, Habermas makes a criticism. He underlines the excess of idealism of the republican model, which makes ethics the indispensable element for its maintenance, supposing then that citizens are inclined to seek common interests. The author defends a third model of deliberation that would overcome republicanism. His argument is based on the fact that, in the presence of individuals with different interests, it is possible, through a deliberative process, to obtain acceptable results for all parties. This author's reflection focuses on the capacity for discussion in public spaces that are opinion-forming and are able to obtain rational and just results. Legitimacy lies in the fact that decisions are derived from democratic processes that express the will of citizens.

The arguments of deliberation, combined with theses on participatory democracy, have been widely explored to explain the increased experiences of citizens' participation. In the theoretical field of participatory democracy that takes place at the local level, normative theories have largely been adopted by contemporary studies. This phenomenon occurred in parallel with a movement of expansion of democratic countries, initiated with the fall of the Berlin Wall.

1.3. E-Democracy. Governments may embrace technological solutions for more efficiency and more rationalized public expenses. Whether it is deliberately or not, democratic processes could be enhanced with such endeavours. E-democracy and e-government are sometimes used as synonyms, which creates a misconception. Norris [28] makes a clear distinction between the two terms. He emphasises that e-democracy (also referred to as e-participation and digital democracy) includes providing accessibility to officials and the archives of government bodies and permitting citizens' participation through information and communication technologies regarding issues of public interest. E-democracy in this stream can be accepted as the electronic participation of citizens in activities that partially disperse government authority, which allows the citizens to directly influence decision-making processes in public-related issues [29-33]. E-government according to [31] has three significant functions: information, transactions, and consultation. Consultation could be either limited engagement or active participation. The latter is known as e-democracy.

The importance of ICT use for democratic processes increases when three factors are guaranteed: information provision, citizens' engagement in policy drawing, and regulatory transformations. This will lead to the partial distribution of authority to citizens through digital participation [34]. Yet, civic participation may differ based on the space of participation e-government platforms allow whether they reach a higher level of deliberation or just be limited to voting [30]. It may still be a Platonic idea to completely involve direct forms of democracy in the Maghreb, but democracy there still needs more deliberative alternatives for real and effective engagement of citizens in politics with and within the existing democratic model, which is a representative model.

\section{Research Model and Hypotheses}

This research tries to investigate the direct and indirect government-led relationship between e-government and participatory democracy as shown in Figure 2. The notion of participatory democracy covers both electoral and nonelectoral political processes, and as highlighted earlier, participatory democracy involves direct democracy as well. Public involvement in political life is being shaped based on the awareness of the general public which, for instance, has created a large debate between the elitist view and the direct participation view of democracy. The expansion of ICT use in governmental and public administration routines has provoked a new way of delivering government services. Therefore, participatory democracy can fit in every democratic model at different levels (representative model, pluralist model, and direct democracy model) which could be also broadened to internet-based public engagement (see [28]). Hence, the following hypothesis is suggested:

H1: E-government quality has a direct positive effect on participatory democracy.

2.1. Transparency and Corruption Control. E-government is expected to play an effective role in reducing corruption. Governments worldwide have been modernizing their services through an electronic presence for income, sales, and property taxes collection, which are normally expected to be a target for corruption. E-government in this sense can be an effective control tool. Vertical and horizontal integration of government systems across applications not only allows real-time authentication, but also assures the traceability of the decisions that are made. The fear of being caught committing wrong-doing and the shame that follows can be a hindrance to corruption-related practices.

When governments share information with the citizens, they actually tend to build accountability through the provision of documentation to citizens, whose endeavour is to restrict corruption. According to Ward [35], transparency is the ability of the general public to see and review the government's practices. Halachmi and Greiling [36] argue that transparency is better achieved when the citizens can reach and control different alternatives to access raw government data. In this research, it is assumed that e-government is one of the best government-citizen communication channels that can perfectly serve this purpose.

Although corruption can be found in public and private sectors in different shapes, it still differs conceptually. In the private sector, there are always alternatives, which is not the case in the public sector where the government has the monopoly of service deliverance or goods supply [37]. Campbell and Lord [38] referred to corruption in the private sector as corporate crime, which includes mistreatment and immoral behaviours towards the stakeholders. However, 


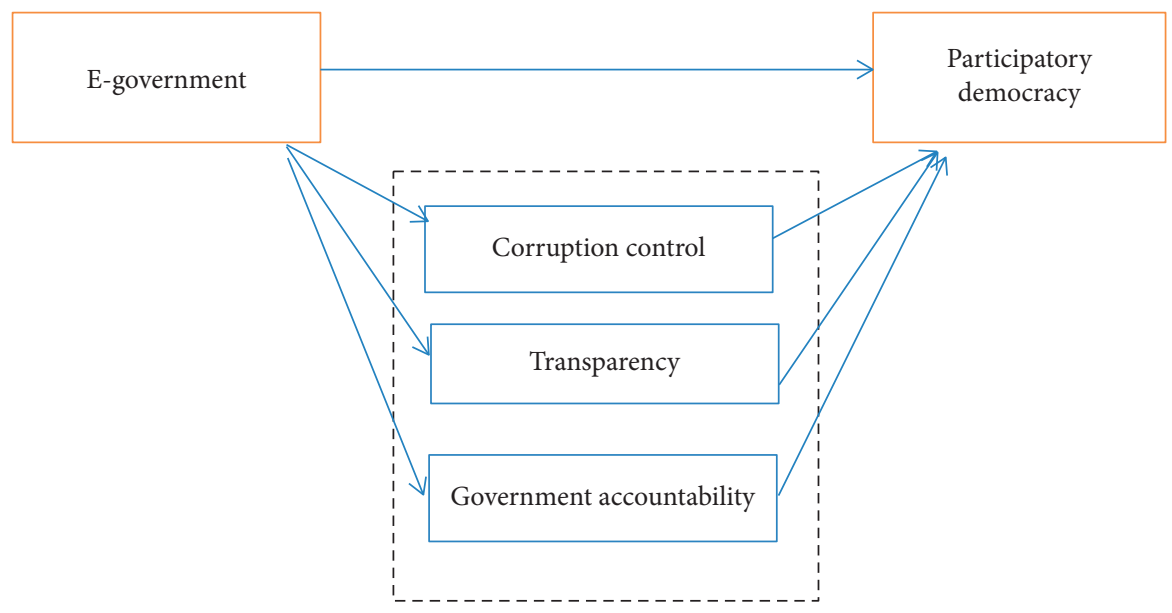

Figure 2: Research model.

corruption in the public sector is the real threat that affects government's performance and confidence when citizens are not treated justly. The proper performance of governments entitles them to solve problems in the private sector. Corruption in the public sector can be divided into petty and grand corruption. According to MacWilliam and Rafferty [39], grand corruption is normally committed by few individuals who use power for huge benefits or amounts of money, whereas petty corruption is committed by normal citizens at a lower administrative level, usually to avoid paying penalties or accessing extra services. Friedrichs [40] uses the term "political white-collar crime" to describe corruption committed by governmental office holders, which is considered as a state crime. This kind of crimes is defined by the World Bank as "bureaucratic corruption" or "administrative corruption." It can also include petty corruption that it is systematic [41].

Mohtadi and Roe ([42], p. 445) believe that corruption augments at the first steps of a country's democratisation process due to the collapse of the old organizational structures. On the other hand, Anderson and Tverdova [43] argue that policymakers should consider the fact that corruption weakens citizens' trust in governments. The mediation effect of corruption control and transparency between e-government and participatory democracy is shown in Figure 2. Therefore, the following hypotheses are suggested:

H2: E-government has an indirect positive effect on participatory democracy through increasing corruption control.

H3: E-government has an indirect positive effect on participatory democracy through increasing transparency.

2.2. Accountability. Modern political theories emphasise that accountability is a core feature of democracy where public authorities are required to assume responsibility for their actions. Accountability, according to Abels [44], fundamentally strengthens the legitimacy of a political system. For Bovens ([45], p. 9), accountability refers to the obligation of an "actor" to justify and explain his actions to a "forum" who is entitled to ask questions, make judgements, and force the "actor" to face the consequences of their actions. In this sense, Nietzsche says that people explain and justify their actions only when they are requested, and only when there is power to back the request ([46], p. 11).

Peters and Wright [47] insist that bureaucrats ought to be accountable to the "customers" of public services. To do so, Bovens [45] says that the accountability process needs to be open to the general public and should be related with public matters. Joss and Mohr [48], discussing the link between accountability and participation, argue that the notion of accountability is directly linked to enhanced citizens' participation. Bovens [45] also links accountability to participation and sees this linkage as a problematic issue since public involvement only plays a preparative role in policy-making and consultation.

E-government, according to several scholars, can play an effective role in enhancing public accountability $[36,49,50]$. E-government can be recognized as an effective tool for promoting government accountability, since it is expected to provide more openness, facilitate citizens' engagement in public decision making, help define and follow suit liability and responsibility, and, most importantly, improve controllability over officials [36, 51, 52]. Kim et al. [52] claim that powerful leadership has a significant role in enhancing online procedures, which leads to the minimization of risk. They argue that better responsiveness, corruption control, and enhanced transparency can improve accountability. E-government, in this sense, increases information loading and sharing between different departments within the integrated systems of e-government, which improves the responsiveness capacity and service quality to the different stakeholders, and eventually increases government accountability [53]. Considering the above, the following hypothesis is suggested:

H4: E-government has an indirect positive effect on participatory democracy through increasing transparency.

\section{Sampling and Methods}

This study attempts to explore the role of government in enabling citizens' direct participation through e-government 
in the Maghreb. For this purpose, a quantitative approach was adopted to examine the relationship between the variables included in the research model. A five-point Likertscale questionnaire was designed and administered to individuals in the three countries (Algeria, Morocco, and Tunisia). Due to the nature of our study, a nonprobability, judgement sampling method was adopted to focus on a population with a specific knowledge and expertise of the process being studied, which is e-government and participatory democracy. The term judgement sampling was used by Deming in his book Some Theory of Sampling in 1950 [54] and before that in 1947 in the Journal of Marketing. This term was introduced to oppose the probability sampling method in the context of surveys. The questionnaire was distributed to the respondents face to face, and 702 responses were collected. Statistical analysis was performed using SPSS 25.0.

Our constructs operationalization is based on the literature. For e-government, we have adopted e-GovQual developed by Papadomichelaki and Mentzas [55] for e-administration and e-service dimensions, whereas a measurement of the e-democracy dimension was developed based on the citizens' web-based political involvement indicators of Scott [56]. For participatory democracy, we have adapted the V-Dem participatory survey developed by Fuchs and Roller [57] considering the electoral and nonelectoral dimensions of participatory democracy. For corruption control, we have adapted from Charron et al. [58] and considered respondents' perceptions and experience regarding the corruption phenomenon in their countries. For transparency, we have adopted the measurement from Kim and Lee [59]. For accountability, we have adopted the measurement of Said et al. [60].

Table 1 shows the research constructs. Five professors evaluated the preliminary version of the questionnaire. Seven professors with field knowledge participated in the evaluation of the final version of the questionnaire, the translation from English to Arabic, and terms familiarization. All referees decided that the questionnaire is a fair measurement.

\section{Results}

4.1. Demographic Characteristics of the Sample. A total of 900 questionnaires were distributed and 702 responses were collected across the three countries: 250 in Algeria, 232 in Morocco, and 220 in Tunisia. Table 2 summarizes the demographic characteristics of our sample in the three countries while descriptive results of each item are shown in Table 3.

4.2. Reliability and Validity. In this part, regression analysis is used to analyse the relationship between the different variables. To validate the measurement model, it is necessary to assess the content, convergent, and discriminant validities as well as the reliability. Content validity was confirmed by fitting our measurements with the literature. To assess reliability, Chin [61] recommended a Cronbach's alpha threshold of 0.7 for each construct. For convergent validity, we adopt Hair et al.'s [62] suggestion using average variance extracted (AVE) and internal composite reliability (ICR). The values of 0.7 for composite reliability and 0.5 for AVE for all measurements as recommended assure significance and convergent validity, as suggested by Fornell and Larcker [63]. Table 4 shows that the reliability, composite reliability, and the average variances extracted values are higher than the recommended values, and therefore, the reliability and convergent validity of all constructs are confirmed.

4.3. Discriminant Validity. The square root of the AVE value has to be higher than its correlation for every variable to confirm the discriminant validity according to Chin [61], which is demonstrated in Table 5.

4.4. Analysis of Constructs and Hypotheses Tests. Hypothesis 1 will be evaluated based on the significance of $t$-statistic, $R^{2}$, and coefficient value of the regression model between the dependent and independent variables. On the other hand, hypotheses 2, 3, and 4 will be evaluated based on the significance of the same values in the two-stage regression model, where in model 1, e-government is the independent variable and participatory democracy is the dependent variable. In model 2, e-government and the mediator are considered as independent variables, whereas participatory democracy is the dependent variable. Table 6 summarizes the hypotheses testing results.

Table 6 shows the significance of all the values. For H1, the results confirm the direct relationship between e-government and participatory democracy.

$\mathrm{H} 2, \mathrm{H} 3$, and $\mathrm{H} 4$ are also accepted since the $t$-statistic, $R^{2}$, coefficient value of the relevant model 2 (as shown in Table 6) are all significant for the three hypotheses, the $R^{2}$ in each test shows an important increase in comparison to model 1, the e-government coefficients in model 2 for $\mathrm{H} 2$, $\mathrm{H} 3$, and H4 decrease compared to the e-government coefficient in model 1, and the excluded model showing regression model between e-government as independent variable and the mediator as dependent variable is significant as well.

\section{Discussion and Conclusion}

Our results explicitly indicate that e-government is indeed positively associated with participatory democracy. Therefore, the performance of governments in the Maghreb countries plays a crucial role stimulating citizens' participation. Statistical analysis confirms the relationship between e-government adoption and participatory democracy in the Maghreb. This means that the more the governments of the three countries enable online communication channels, the more citizens' engagement will increase, which is consistent with the recent studies [64-67]. We found that the nonelectoral dimension of participatory democracy is significant in the Maghreb countries, although Tunisia slightly stands out in terms of women's empowerment and civil society participation. 
TABLE 1: Research constructs.

\begin{tabular}{|c|c|c|}
\hline Variables & Items & Source \\
\hline $\begin{array}{l}\text { E-government } \\
\text { quality }\end{array}$ & 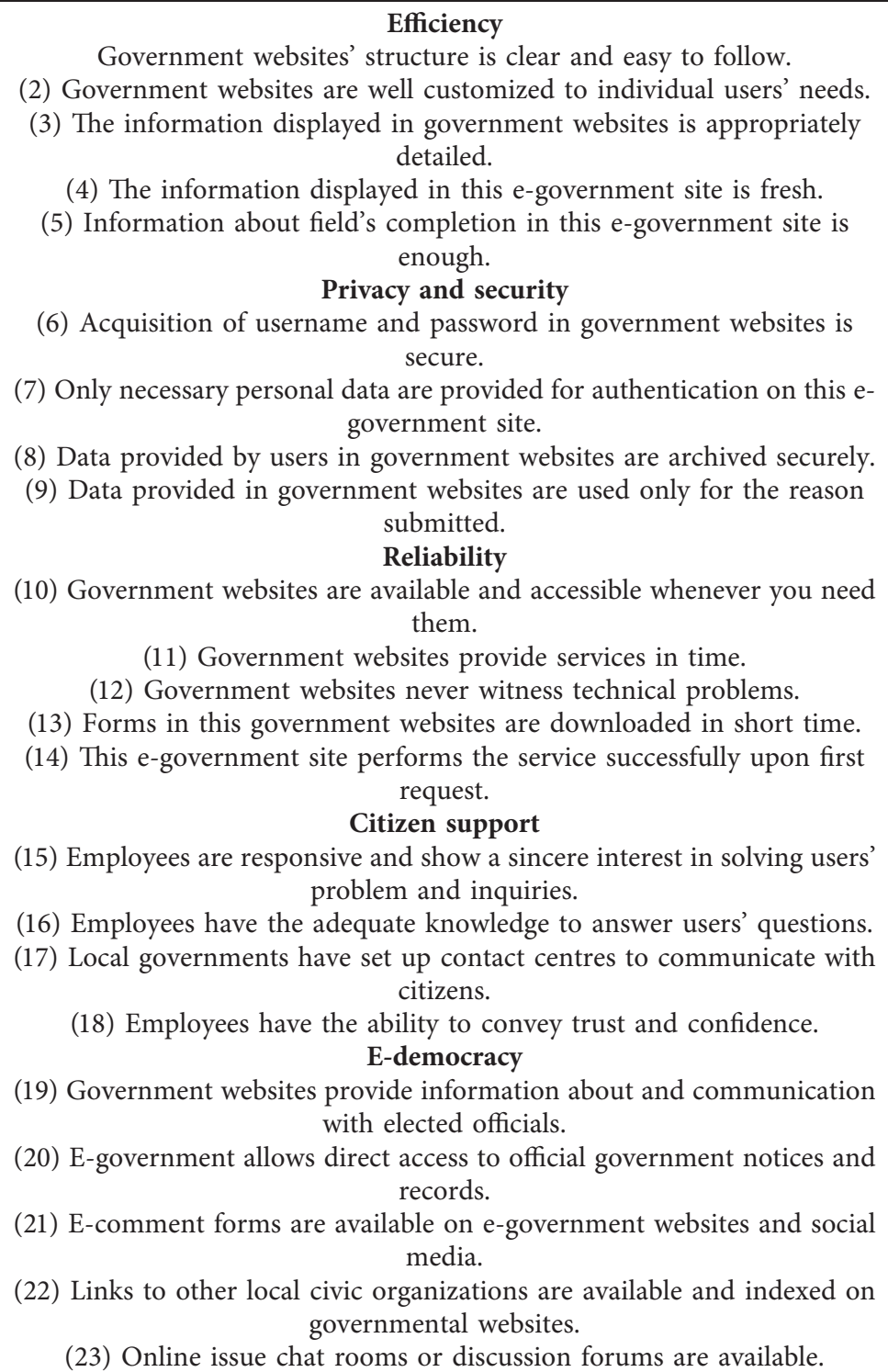 & Papadomichelaki and Mentzas [55] \\
\hline
\end{tabular}


TABLE 1: Continued.

\begin{tabular}{|c|c|c|}
\hline Variables & Items & Source \\
\hline $\begin{array}{l}\text { Participatory } \\
\text { democracy }\end{array}$ & $\begin{array}{l}\text { Electoral democracy } \\
\text { (24) Rulers are responsive to citizens. } \\
\text { (25) Political and civil society organizations can operate freely. } \\
\text { (26) Elections are clean and not marred by fraud or systematic irregularities. } \\
\text { (27) People choose their leaders in free elections. } \\
\text { (28) Electoral competition for the electorate's approval under circumstances } \\
\text { when suffrage is extensive. } \\
\text { (29) Elections affect the composition of the chief executive of the country. } \\
\text { (30) In between elections, there is freedom of expression and an } \\
\text { independent media capable of presenting alternative views on matters of } \\
\text { political relevance. } \\
\text { Nonelectoral } \\
\text { (31) Legislative candidate selection within the parties is not centralized. } \\
\text { (32) Women are encouraged to participate in civil society organizations } \\
\text { (CSOs). } \\
\text { (33) Women have the same rights as men. } \\
\text { (34) People are involved in civil society organizations (CSOs). } \\
\text { (35) People can change the laws in referendums. }\end{array}$ & $\begin{array}{l}\text { Adopting V-Dem participatory } \\
\text { survey of Fuchs et al. [57] }\end{array}$ \\
\hline Corruption control & $\begin{array}{l}\text { Perceptions } \\
\text { (36) There is need corruption* in my country. } \\
\text { (37) There is greed corruption**in my country. } \\
\text { (38) Elections are clean from corruption. } \\
\text { (39) Law enforcement faces difficulties due to administrative corruption or } \\
\text { interference of people from higher authorities. } \\
\text { Experiences } \\
\text { (40) I am frequently asked to pay a bribe for a public service. } \\
\text { (41) I am frequently obliged to pay a bribe for a public service. } \\
\text { (42) I frequently hear my acquaintances complaining about the corruption } \\
\text { in public administration. }\end{array}$ & Adapted from Charron et al. [58] \\
\hline Transparency & $\begin{array}{l}\text { (43) Governments' online services have been more transparent. } \\
\text { (44) Public employees' engagement in corruption has been reduced. } \\
\text { (45) Government websites have provided the citizens with greater } \\
\text { opportunities to participate in the rulemaking process. } \\
\text { (46) E-government has provided the citizens with an equal opportunity to } \\
\text { participate in the rulemaking process. }\end{array}$ & Kim et al. [59] \\
\hline $\begin{array}{l}\text { Government's } \\
\text { accountability }\end{array}$ & $\begin{array}{l}\text { (47) The government supports the process of learning from mistakes and } \\
\text { successes and consider external views for improvement. } \\
\text { (48) The government has a regular reporting system on the achievements } \\
\text { and results of programs or projects against objectives. } \\
\text { (49) The government recognizes the responsibilities of the organization } \\
\text { toward its community, society, and the environment. } \\
\text { (50) The government follows treasury rules and regulations in all } \\
\text { circumstances. } \\
\text { (51) The government ensures proper usage of funds in an authorized } \\
\text { manner. } \\
\text { (52) The government provides higher responsibility to employees to become } \\
\text { highly efficient and effective. }\end{array}$ & Said et al. [60] \\
\hline
\end{tabular}

Algeria, like Morocco and Tunisia, has been modernizing public administration online services in terms of readiness, effectiveness, responsiveness, and security through vertical and horizontal integration of government systems. Experts' answers reflect a very positive impression regarding the quality of e-government in each country. According to the e-government development index, Tunisia is a regional leader. Our statistical conclusion indicates that e-government has a significant role and are already resulting benefits regarding corruption control. Shim and Eom [68] explained this relationship claiming that increasing the effectiveness of internal controllability over managers through e-government prevents corruption attempts and reinforces government accountability and transparency.

The fact that e-government has anticorruption capabilities is based on its ability to trace operations processes, in terms of both delivered services and internal workflows. Therefore, e-government helps to enhance vertical surveillance over public servants and their activities. However, the introduction of e-government may not be to the sole method of confronting corrupt activities. Nevertheless, the maturity and the security levels of the system play significant roles in 
TABLE 2: Demographic characteristics of the research sample.

\begin{tabular}{|c|c|c|c|c|c|c|}
\hline & & Algeria & Morocco & Tunisia & Total & $\%$ \\
\hline \multirow{6}{*}{ Age } & $18-25$ & 30 & 32 & 16 & 78 & 11 \\
\hline & $26-30$ & 32 & 76 & 63 & 171 & 24 \\
\hline & $31-35$ & 65 & 65 & 69 & 199 & 28 \\
\hline & $36-40$ & 37 & 37 & 39 & 113 & 16 \\
\hline & $41-50$ & 37 & 6 & 20 & 63 & 9 \\
\hline & $51-60$ & 49 & 16 & 13 & 78 & 11 \\
\hline \multirow{2}{*}{ Gender } & Female & 120 & 104 & 95 & 319 & 45 \\
\hline & Male & 130 & 128 & 125 & 383 & 55 \\
\hline \multirow{3}{*}{ Education } & Bachelor's & 114 & 120 & 104 & 338 & 48 \\
\hline & Master's & 98 & 75 & 81 & 254 & 36 \\
\hline & Ph.D. & 38 & 37 & 35 & 110 & 16 \\
\hline \multirow{6}{*}{ Categories } & Experts (ICT, media, and academicians) & 39 & 37 & 38 & 114 & 16 \\
\hline & Government officers & 45 & 38 & 34 & 117 & 17 \\
\hline & Lawmen & 40 & 36 & 32 & 108 & 15 \\
\hline & NGO & 39 & 40 & 38 & 117 & 17 \\
\hline & Political parties & 41 & 38 & 42 & 121 & 17 \\
\hline & Public administrators & 46 & 43 & 36 & 125 & 18 \\
\hline
\end{tabular}

TABLE 3: Summarizes results of participants' answers based on measures of central tendency for each item.

\begin{tabular}{|c|c|c|c|c|c|}
\hline & $\mathrm{N}$ & Minimum & Maximum & Mean & Std. deviation \\
\hline E-gov1 & 702 & 1 & 5 & 3.43 & 0.927 \\
\hline E-gov2 & 702 & 1 & 5 & 3.13 & 1.016 \\
\hline E-gov3 & 702 & 1 & 5 & 3.45 & 0.960 \\
\hline E-gov4 & 702 & 1 & 5 & 3.45 & 0.960 \\
\hline E-gov5 & 702 & 1 & 5 & 3.13 & 1.016 \\
\hline E-gov6 & 702 & 1 & 5 & 3.71 & 1.252 \\
\hline E-gov7 & 702 & 1 & 5 & 3.71 & 1.252 \\
\hline E-gov8 & 702 & 1 & 5 & 3.77 & 1.240 \\
\hline E-gov9 & 702 & 1 & 5 & 3.77 & 1.240 \\
\hline E-gov10 & 702 & 1 & 5 & 3.64 & 1.280 \\
\hline E-gov11 & 702 & 1 & 5 & 2.46 & 1.078 \\
\hline E-gov12 & 702 & 1 & 5 & 3.64 & 1.280 \\
\hline E-gov13 & 702 & 1 & 5 & 3.64 & 1.280 \\
\hline E-gov14 & 702 & 1 & 5 & 2.46 & 1.078 \\
\hline E-gov15 & 702 & 1 & 5 & 2.45 & 1.018 \\
\hline E-gov16 & 702 & 1 & 5 & 2.95 & 1.054 \\
\hline E-gov17 & 702 & 1 & 5 & 2.95 & 1.054 \\
\hline E-gov18 & 702 & 1 & 5 & 2.45 & 1.018 \\
\hline E-dem 1 & 702 & 1 & 5 & 3.20 & 1.091 \\
\hline E-dem 2 & 702 & 1 & 5 & 3.19 & 1.090 \\
\hline E-dem 3 & 702 & 1 & 5 & 3.24 & 1.209 \\
\hline E-dem 4 & 702 & 1 & 5 & 2.34 & 1.038 \\
\hline E-dem 5 & 702 & 1 & 5 & 3.41 & 1.237 \\
\hline PartDem1 & 702 & 1 & 5 & 2.80 & 1.049 \\
\hline PartDem2 & 702 & 1 & 5 & 3.42 & 1.296 \\
\hline PartDem3 & 702 & 1 & 5 & 3.12 & 1.408 \\
\hline PartDem4 & 702 & 1 & 5 & 3.12 & 1.408 \\
\hline PartDem5 & 702 & 1 & 5 & 3.42 & 1.296 \\
\hline PartDem6 & 702 & 1 & 5 & 2.80 & 1.049 \\
\hline Part-Dem7 & 702 & 1 & 5 & 3.12 & 1.408 \\
\hline PartDem8 & 702 & 1 & 5 & 2.58 & 1.144 \\
\hline PartDem9 & 702 & 1 & 5 & 3.57 & 1.051 \\
\hline PartDem 10 & 702 & 1 & 5 & 3.78 & 1.269 \\
\hline PartDem11 & 702 & 1 & 5 & 3.03 & 0.974 \\
\hline PartDem12 & 702 & 1 & 5 & 2.18 & 1.309 \\
\hline CrptnCtrl1 & 702 & 1 & 5 & 2.22 & 1.263 \\
\hline CrptnCtrl2 & 702 & 1 & 5 & 1.76 & 1.022 \\
\hline CrptnCtrl3 & 702 & 1 & 5 & 3.12 & 1.408 \\
\hline
\end{tabular}


TABLE 3: Continued.

\begin{tabular}{|c|c|c|c|c|c|}
\hline & $\mathrm{N}$ & Minimum & Maximum & Mean & Std. deviation \\
\hline CrptnCtrl4 & 702 & 1 & 5 & 3.09 & 1.281 \\
\hline CrptnCtrl5 & 702 & 1 & 5 & 3.09 & 1.281 \\
\hline CrptnCtrl6 & 702 & 1 & 5 & 3.47 & 1.325 \\
\hline CrptnCtrl7 & 702 & 1 & 5 & 3.47 & 1.325 \\
\hline Tran1 & 702 & 1 & 5 & 2.91 & 1.050 \\
\hline Tran2 & 702 & 1 & 5 & 2.39 & 1.103 \\
\hline Tran3 & 702 & 1 & 5 & 2.16 & 1.083 \\
\hline Tran4 & 702 & 1 & 5 & 2.34 & 1.070 \\
\hline Gov-acc1 & 702 & 1 & 5 & 2.76 & 1.118 \\
\hline Gov-acc2 & 702 & 1 & 5 & 2.76 & 1.118 \\
\hline Gov-acc3 & 702 & 1 & 5 & 2.98 & 1.130 \\
\hline Gov-acc4 & 702 & 1 & 5 & 2.98 & 1.130 \\
\hline Gov-acc5 & 702 & 1 & 5 & 2.49 & 1.085 \\
\hline Gov-acc6 & 702 & 1 & 5 & 2.49 & 1.085 \\
\hline
\end{tabular}

TABLE 4: Cronbach's alpha, composite reliability, and average variance extracted (AVE).

\begin{tabular}{lcccc}
\hline Variables & Cronbach's alpha & Composite reliability & Average variance extracted (AVE) & Square root of AVE \\
\hline E_gov & 0.956 & 0.940 & 0.568 & 0.753 \\
Part_dem & 0.905 & 0.872 & 0.589 & 0.767 \\
Crptnctrl & 0.787 & 0.787 & 0.529 & 0.728 \\
Tran & 0.829 & 0.797 & 0.591 & 0.769 \\
Gov_acc & 0.956 & 0.817 & 0.528 & 0.727 \\
\hline
\end{tabular}

TABle 5: Correlation matrix and square root of AVE.

\begin{tabular}{|c|c|c|c|c|c|c|}
\hline & Egov & PartDem & CrptnCtrl & Tran & Govacc & Square root of AVE \\
\hline Egov & 1 & & & & & \\
\hline PartDem & $0.701^{* *}$ & 1 & & & & 0.767 \\
\hline CrptnCtrl & $0.317^{* *}$ & $0.384^{* *}$ & 1 & & & 0.728 \\
\hline Tran & $0.525^{* *}$ & $0.581^{* *}$ & $0.306^{* *}$ & 1 & & 0.769 \\
\hline Govacc & $0.570^{* *}$ & $0.554^{* *}$ & $0.341^{* *}$ & $0.528^{* *}$ & 1 & 0.727 \\
\hline
\end{tabular}

** Correlation is significant at the 0.01 level (2-tailed).

TABLE 6: Hypotheses testing results.

\begin{tabular}{|c|c|c|c|c|c|c|}
\hline Hypotheses & Models & Effect & $R^{2}$ & Coefficient $(\beta)$ & $t$-statistic & Remarks \\
\hline H1 & Model 1 & E-gov-- > PartDem & 0.491 & 0.701 & 25.97 & Supported \\
\hline H2 & $\begin{array}{c}\text { Model } 2 \\
\text { Excluded model }\end{array}$ & $\begin{array}{c}\text { E-gov, CrptnCtrl-- > PartDem } \\
\text { E-gov-- > CrptnCtrl }\end{array}$ & 0.52 & $\begin{array}{c}\beta 1=0.643, \beta 2=0.180 \\
0.295\end{array}$ & $\begin{array}{c}T 1=23.288, T 2=6.513 \\
9.929\end{array}$ & Supported \\
\hline H3 & $\begin{array}{c}\text { Model } 2 \\
\text { Excluded model } \\
\end{array}$ & $\begin{array}{c}\text { E-gov, trans-- > PartDem } \\
\text { E-gov-- > trans }\end{array}$ & 0.525 & $\begin{array}{c}\beta 1=0.584, \beta 2=0.192 \\
0.224\end{array}$ & $\begin{array}{c}T 1=18.184, T 2=7.100 \\
7.1\end{array}$ & $\mathrm{Su}$ \\
\hline$H 4$ & $\begin{array}{c}\text { Model } 2 \\
\text { Excluded model }\end{array}$ & $\begin{array}{c}\text { E-gov, acc-- > PartDem } \\
\text { E-gov-- > acc }\end{array}$ & 0.54 & $\begin{array}{c}\beta 1=0.436, \beta 2=0.370 \\
0.277\end{array}$ & $\begin{array}{c}T 1=10.568, T 2=8.697 \\
8.697\end{array}$ & rted \\
\hline
\end{tabular}

$P<0.001$.

the success of e-government in general and its anticorruption role in particular.

E-government can detect whether regulations and rules are respected while performing procedures. When anomalies appear, they must be confronted with strict correcting reactions that must be taken immediately. Otherwise, the role of e-government will be very limited in corruption control. To reinforce the role of e-government systems confronting corruption, features such as whistleblowers and laws to protect the whistleblower should be considered. By reducing the direct contact between citizens and public servants, e-government restricts the opportunity to request bribes [69]. Previous experiences of countries in Europe, the Americas, and Asia have confirmed the efficiency of e-government in corruption control $[68,70]$.

The other outcome of e-government is enhanced transparency, which represents a good way of supporting the application of already existing laws that emphasise the rights 
of citizens to access information. Until recently, many countries indeed applied secrecy laws that constrained citizens and public opinion. In parallel with the adoption of e-government and the growth of freedom of information access rights that are pushed by citizens and supported by laws in North Africa, strict secrecy laws have retreated. These kinds of laws are a feature of many developing countries; therefore, e-government represents a real challenge against these secrecy laws. It requires a strong will from the government towards real and factual openness. Optimal implementation of transparency laws is subject to the comprehensive use of ICTs to deliver government services [71]. E-government in general and in the Maghreb in particular must not be considered as a tool only used increase access to information, but rather as a means to ensure that rules and regulations are transparent and respected as well. This would make it possible to trace any action or decision made through e-government systems.

Our results show that e-government has a significant positive effect on public accountability. This confirms the claims of several scholars [36, 49-52]. E-government can increase public accountability by promoting good and transparent governance, increasing managerial surveillance, reducing opportunities for corrupt behaviours, and giving a chance to citizens to track transactions and complain to higher management. By providing openness and defining the hierarchy of liability and responsibility of backstage users, e-government can enhance controllability over officials.

In fact, the three notions of transparency, corruption control, and accountability are complementarily interrelated and ultimately serve the purpose of each other. Therefore, the fact that e-government is proved as a factor that enhances transparency explains why it should be able to enhance corruption control and public accountability. The transparency of transactions enabled by e-government can detect and trace back mistakes and corrupt behaviours in case any action was against the rules and regulations and against the public interest, and ultimately, the involved parties will be held accountable for their actions.

Participatory democracy is affected indirectly by e-government through enhanced government performance in terms of transparency, corruption control, and accountability. When citizens see their contributions rewarded and their will implemented, their engagement increases. Citizens' engagement in the electoral and nonelectoral dimensions of participatory democracy is related to their ability to control and question government choices and their ability and free will to choose and change. Therefore, e-government is not only regarded as a direct enabler of participation through its e-democracy dimension, but also as an indirect factor that motivates citizens' participation through its influence on government performance and legitimacy.

We have focused on participatory democracy as it is a crossroads whereby developing countries have the opportunity to catch up with developed countries in their democratic experience. While democracy in developing countries is similar to that in developed countries in form but not necessarily in content, the practice of democracy in both worlds differs due to the cultural heritage, the length of experience, and traditions that span centuries, which distinguishes the occident. Giving way to participatory democracy in developing countries would return to it the missed content and decrease the gap. We have found that e-government is a way of shortening distance and reducing time to the Maghreb countries to revive the democratic experience by intensifying citizens' participation.

One of the most serious issues of democracy in developing countries is the vague state that surrounds various government measures and decisions. As a result, corruption spreads due to the lack of standards in decision-making, the selection of individuals, and the distribution of positions. This fact leads to a state of negativity among citizens and lack of confidence in the government's seriousness to carry out its tasks and the real involvement of citizens in decisionmaking.

In light of this view, e-government can enhance transparency, reduce corruption, and raise the degree of accountability. This would boost citizens' empowerment endeavours and their involvement in civil society organizations.

This paper focused on the enhancement of government performance via e-government, which ultimately leads to better engagement of citizens in public issues. At the end of this paper, we would like to suggest topics for future studies. One aspect not covered by this paper is the effect of e-government on citizens' attitudes in terms of trust and citizenship, which may lead to more deliberation efforts. Another topic we would like to suggest in question form is, "Does e-democracy threaten the traditional political ideologies?"

\section{Data Availability}

The cross-sectional data used to support the findings of this study are available from the corresponding author upon request (esselimanisami@gmail.com and sami_esc@ yahoo.fr).

\section{Conflicts of Interest}

The authors declare that they have no conflicts of interest regarding the publication of this paper.

\section{References}

[1] D. Vitale, "Between deliberative and participatory democracy," Philosophy \& Social Criticism, vol. 32, no. 6, pp. 739-766, 2006.

[2] J. Sangki, "Vision of future e-government via new e-government maturity model: based on Korea's e-government practices," Telecommunications Policy, vol. 42, no. 10, pp. 860-871, 2018.

[3] J. S. Hiller and F. Bélanger, "Privacy strategies for electronic government," E-government, vol. 200, pp. 162-198, 2001.

[4] C. G. Wescott, "E-Government in the Asia-pacific region," Asian Journal of Political Science, vol. 9, no. 2, pp. 1-24, 2001. 
[5] B. W. Wirtz and P. Daiser, E-government. Strategy Process Instruments, Deutsche Universität für Verwaltungswissenschaften Speyer, Speyer, Germany, 2015.

[6] U. Nations, E-government for the Future We Want. United Nations E-Government Survey 2014, 2014.

[7] A. DeBenedictis, W. Howell, R. Figueroa, and R. Boggs, "Egovernment defined: an overview of the next big information technology challenge," Issues in Information Systems, vol. 3, no. 1, pp. 130-136, 2002.

[8] V. Homburg, Understanding E-Government: Information Systems in Public Administration, Routledge, Philadelphia, PA, USA, 2008.

[9] G. Grant and D. Chau, "Developing a generic framework for e-Government," in Advanced Topics in Global Information Management, Carleton University, Ottawa, Canada, 2006.

[10] I. Bernhard, E-government and E-governance: Swedish Case Studies with Focus on the Local Level, KTH Royal Institute of Technology, Stockholm, Sweden, 2013.

[11] E. Wihlborg, Offentliga E-Tjänster I Medborgarens Tjänst: Finansdepartementet Delegationen För Tjugofyratimmarsmyndigheten[Public E-Services in the Service of the Citizen: Ministry of Finance, 2005.

[12] G. Jansson, Local Values and E-Government-Continuity and Change in Public Administration: Implementing Public E-Services in Two Swedish Municipalities, Linköping University Electronic Press, Linköping, Sweden, 2011.

[13] K. Giritli Nygren and H. G. Wiklund, En IT-styrd förvaltning: en fjärde förvaltningsdoktrin?, 2010.

[14] A. Gronlund, "What's in a field-exploring the egoverment domain," in Proceedings of the 38th Annual Hawaii International Conference on System Sciences, Washington, NJ, USA, January 2005.

[15] M. Vintar, M. Kunstelj, M. Dečman, and B. Berčič, "Development of e-government in Slovenia," Information Polity, vol. 8, no. 3, pp. 133-149, 2003.

[16] K. Layne and J. Lee, "Developing fully functional E-government: a four stage model," Government Information Quarterly, vol. 18, no. 2, pp. 122-136, 2001.

[17] A. Cordelia, "E-government: towards the e-bureaucratic form?" Journal of Information Technology, vol. 22, no. 3, pp. 265-274, 2007.

[18] F. Kolegar, "The elite and the ruling class: Pareto and Mosca Re-examined," The Review of Politics, vol. 29, no. 3, pp. 354-369, 1967.

[19] G. O'donnell and J. V. Cullell, The Quality of Democracy: Theory and Applications, University of Notre Dame Pess, Notre Dame, IN, USA, 2004.

[20] A. Fung and E. O. Wright, Deepening Democracy: Institutional Innovations in Empowered Participatory Governance, Verso, Miamisburg, OH, USA, 2003.

[21] C. W. Lubambo, D. B. Coelho, and M. A. Melo, "Diseño institucional y participación política," Experiencias en el Brasil contemporáneo, CLACSO, Buenos Aires, Argentina, 2006.

[22] F. Dondero, A. Dagnino, H. Jonsson, F. Caprì, L. Gastaldi, and A. Viarengo, "Assessing the occurrence of a stress syndrome in mussels (Mytilus edulis) using a combined biomarker/gene expression approach," Aquatic Toxicology, vol. 78, pp. S13S24, 2006.

[23] D. Held, Models of Democracy, Stanford University Press, Palo Alto, CA, USA, 2006.

[24] C. Pateman, Participation and Democratic Theory, Cambridge University Press, Cambridge, UK, 1970.

[25] C. Pateman, "Participatory democracy revisited," Perspectives on Politics, vol. 10, no. 1, pp. 7-19, 2012.
[26] B. Benjamin, Strong Democracy: Participatory Politics for a New Age, University of California, Los Angeles, CA, USA, 1984.

[27] J. Habermas, The Structural Transformation of the Public Sphere: An Inquiry into a Category of Bourgeois Society Trans, Thomas Burger with Frederick Lawrence, Cambridge, UK, 1995.

[28] D. F. Norris, "e-government... not e-governance... not e-democracy not now! not ever?" in Proceedings of the 4th International Conference on Theory and Practice of Electronic Governance, Beijing China, October 2010.

[29] A. Bruns, "Towards distributed citizen participation: lessons from WikiLeaks and the queensland floods," JeDEM-eJournal of eDemocracy and Open Government, vol. 4, no. 2, pp. 142-159, 2012.

[30] E. De Blasio and M. Sorice, "E-democracy and digital activism: from divergent paths toward a new frame," International Journal of Communication, vol. 13, pp. 5715-5733, 2019.

[31] J. Freeman and S. Quirke, "Understanding E-democracy government-led initiatives for democratic reform," JeDEMeJournal of eDemocracy and Open Government, vol. 5, no. 2, pp. 141-154, 2013

[32] M. Margolis and G. Moreno-Riaño, Democracy Tolerance and the Internet. The Prospect of Internet Democracy, Surrey \& Burlington Ashgate, Farnham, UK, 2009.

[33] P. Norris, Digital Divide: Civic Engagement Information Poverty and the Internet Worldwide, Cambridge University Press, Cambridge, UK, 2001.

[34] P. Henman, Governing Electronically: E-Government and the Reconfiguration of Public Administration Policy and Power, Springer, Berlin, Germany, 2010.

[35] S. J. Ward, "The magical concept of transparency," Ethics for Digital Journalists: Emerging Best Practices, vol. 45, pp. 45-58, 2014.

[36] A. Halachmi and D. Greiling, "Transparency e-government and accountability: Some issues and considerations," Public Performance \& Management Review, vol. 36, no. 4, pp. 562584, 2013.

[37] M. Bauhr, "Need or greed? Conditions for collective action against corruption," Governance, vol. 30, no. 4, pp. 561-581, 2017.

[38] L. Campbell and N. Lord, Corruption in Commercial Enterprise: Law Theory and Practice, Routledge, Philadelphia, PA, USA, 2018.

[39] S. MacWilliam and M. Rafferty, "From development and grand corruption to governance," International Journal for Crime, Justice and Social Democracy, vol. 6, no. 4, p. 12, 2017.

[40] D. O. Friedrichs, "State crime or governmental crime: making sense of the conceptual confusion," in Controlling State Crime, pp. 53-80, Taylor \& Francis, Oxford, UK, 2000, https://scholar. google.com/scholar?hl=en\&as_sdt=0\%2C5\&q=D.+O.+Friedrich s\%2C+\%E2\%80\%9CState+crime+or+governmental+crime $\% 3 \mathrm{~A}$ +making+sense+of + the+conceptual+confusion $\% 2 \mathrm{C} \% \mathrm{E} 2 \% 80 \%$ $9 \mathrm{D}+$ Controlling+State+Crime $\% 2 \mathrm{C}+$ pp. $+53 \% \mathrm{E} 2 \% 80 \% 9380 \% 2 \mathrm{C}$ +2000 . \&btnG $=$.

[41] P. Yanguas and B. Bukenya, “New” approaches confront "old" challenges in African public sector reform," Third World Quarterly, vol. 37, no. 1, pp. 136-152, 2016.

[42] H. Mohtadi and T. L. Roe, "Democracy rent seeking public spending and growth," Journal of Public Economics, vol. 87, no. 3-4, pp. 445-466, 2003.

[43] C. J. Anderson and Y. V. Tverdova, "Corruption, political allegiances, and attitudes toward government in 
contemporary democracies," American Journal of Political Science, vol. 47, no. 1, pp. 91-109, 2003.

[44] G. Abels, "Citizen involvement in public policy-making: does it improve democratic legitimacy and accountability? The case of pTA," Interdisciplinary Information Sciences, vol. 13, no. 1, pp. 103-116, 2007.

[45] M. Bovens, How Management Matters: Street-Level Bureaucrats and Welfare Reform, Blackwell Publishing 9600 Garsington RD, Oxford, England, 2006.

[46] J. Butler, Giving an Account of Oneself, 2005.

[47] B. G. Peters and V. Wright, "Public policy and administration old and new," A New Handbook of Political Science, Oxford University Press Inc., New York, NY, USA, 1996.

[48] S. Joss and A. Mohr, Analysing Public Accountability Procedures in Contemporary European Contexts: Public Accountability (PubAcc) Project-Final Report, HPSE-CT2001-0076, Westminster University, London, UK, 2004.

[49] S. Haque and P. Pathrannarakul, "E-Government towards good governance: a global appraisal," Journal of E-Governance, vol. 36, no. 1, pp. 25-34, 2013.

[50] W. Wong and E. Welch, "Does E-government promote accountability? A comparative analysis of website openness and government accountability," Governance, vol. 17, no. 2, pp. 275-297, 2004.

[51] J. B. Justice, J. Melitski, and D. L. Smith, "E-government as an instrument of fiscal accountability and responsiveness," The American Review of Public Administration, vol. 36, no. 3, pp. 301-322, 2006.

[52] S. Kim, H. J. Kim, and H. Lee, "An institutional analysis of an e-government system for anti-corruption: the case of OPEN," Government Information Quarterly, vol. 26, no. 1, pp. 42-50, 2009.

[53] V. Pina, L. Torres, and B. Acerete, "Are ICTs promoting government accountability?: a comparative analysis of e-governance developments in 19 OECD countries," Critical Perspectives on Accounting, vol. 18, no. 5, pp. 583-602, 2007.

[54] W. E. Deming, Some Theory of Sampling, John Wiley \& Sons, Hoboken, NJ, USA, 1950.

[55] X. Papadomichelaki and G. Mentzas, "e-GovQual: a multipleitem scale for assessing e-government service quality," Government Information Quarterly, vol. 29, no. 1, pp. 98-109, 2012.

[56] J. K. Scott, “"E” the people: do U.S. Municipal government web sites support public involvement?" Public Administration Review, vol. 66, no. 3, pp. 341-353, 2006.

[57] D. Fuchs and E. Roller, "Conceptualizing and measuring the quality of democracy: the citizens' perspective," Politics and Governance, vol. 6, no. 1, pp. 22-32, 2018.

[58] N. Charron, V. Lapuente, and P. Annoni, "Measuring quality of government in EU regions across space and time," Papers in Regional Science, vol. 98, no. 5, pp. 1925-1953, 2019.

[59] S. Kim and J. Lee, "E-participation, transparency, and trust in local government," Public Administration Review, vol. 72, no. 6, pp. 819-828, 2012.

[60] J. Said, M. M. Alam, and M. A. B. A. Aziz, "Public accountability system: empirical assessment of public sector of Malaysia," Asian Journal of Scientific Research, vol. 8, no. 2, pp. 225-236, 2015.

[61] W. W. Chin, "The partial least squares approach to structural equation modeling," Modern Methods for Business Research, vol. 295, no. 2, pp. 295-336, 1998.

[62] J. Hair, R. Anderson, R. Tatham, and W. Black, Multivariate Data Analysis, Prentice Hall International, New York, NY, USA, 5th edition, 1998.
[63] C. Fornell and D. F. Larcker, "Evaluating structural equation models with unobservable variables and measurement error," Journal of Marketing Research, vol. 18, no. 1, pp. 39-50, 1981.

[64] A. Gerunov, "Effects of open E-government on democracy: a public value perspective,” Климент Очридски, vol. 19, no. 1, pp. 31-40, 2020.

[65] N. Goodman and L. C. Stokes, "Reducing the cost of voting: an evaluation of internet voting's effect on turnout," British Journal of Political Science, vol. 50, no. 3, pp. 1155-1167, 2020.

[66] K. LeRoux, F. Fusi, and A. G. Brown, "Assessing e-government capacity to increase voter participation: evidence from the U.S," Government Information Quarterly, vol. 37, no. 3, p. 101483, 2020.

[67] J. Yu, "Does state online voter registration increase voter turnout?" Social Science Quarterly vol. 100, no. 3, pp. 620-634, 2019.

[68] D. C. Shim and T. H. Eom, "E-government and anti-corruption: empirical analysis of international data," International Journal of Public Administration, vol. 31, no. 3, pp. 298-316, 2008.

[69] J. Anderson, A Review of Governance and Anti-corruption Indicators in East Asia and Pacific, World Bank, Washington, NJ, USA, 2009.

[70] S. Bhatnagar, Transparency and Corruption: Does E-Government Help, pp. 1-9, DRAFT Paper prepared for the compilation of CHRI, 2003.

[71] J. E. Relly and M. Sabharwal, "Perceptions of transparency of government policymaking: a cross-national study," Government Information Quarterly, vol. 26, no. 1, pp. 148-157, 2009. 